\title{
Performance and Risks: Islamic Indices Compared to Conventional Indices
}

\section{Jamal Agouram ${ }^{1}$ Jamaa Anoualigh ${ }^{2}$ Lhoucine Ben Hssain ${ }^{3}$ Ghizlane Lakhnati ${ }^{4}$}

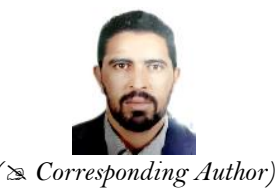

${ }_{1,3,4}$ LISAD-ENSA, Ibn zohr University, Agadir, Morocco. 'Email:jamal.agouram@edu.uiz.ac.ma Tel:+212661653888 Email:Ihoucine.benhssain@edu.uiz.ac.maTel:+212658715882 ‘Email: g.lakhnati@uiz.ac.ma Tel: +212662685274

${ }^{2}$ Faculty of Law, Economics and Social Sciences, Ibn zohr University, Agadir, Morocco.

Email:anoualighjamaa@gmail.com Tel:+212673222634.

\section{Abstract}

Islamic finance is very successful in the global market, and leading traditional index providers have expanded their range and are now offering a multitude of Islamic indices to facilitate the rapid development of Islamic finance, especially Sharia-compliant funds. This study evaluates and analyzes both Islamic and non-Islamic indices and their volatility, considering Islamic finance's rise in popularity. The purpose of this research is to establish a comparison and then analyze the results of the performance of the Dow Jones World Index (DJW) and its Islamic counterparts. The analysis of the outcomes will be in terms of performance measures. On the basis of the total risk, we will then compare the Dow Jones World Index and its Islamic counterparts. This risk would usually be captured by both the value-at-risk $(\mathrm{VaR})$ and the conditional value-at-risk $(\mathrm{CVaR})$. The purpose of this paper is to demonstrate whether Islamic indices are higher than the conventional indices and whether the overall risk for Islamic indices is lower than for conventional indices.

Keywords: Conditional value-at-risk, Dow Jones World Index (DJW), GARCH(1,1), Islamic investment, Performance, Value-at-risk JEL Classification: F37.

Citation | Jamal Agouram; Jamaa Anoualigh; Lhoucine Ben Hssain; Ghizlane Lakhnati (2021). Performance and Risks: Islamic Indices Compared to Conventional Indices. Asian Journal of Economics and Empirical Research, 8(1): 17-26.

History:

Received: 26 January 2021

Revised: 2 March 2021

Accepted: 29 March 2021

Accepted: 29 March 2021

Licensed: This work is licensed under a Creative Commons Attribution 3.0 License (cc)

Publisher: Asian Online Journal Publishing Group
Acknowledgement: All authors contributed to the conception and design of the study.

Funding: This study received no specific financial support.

Competing Interests: The authors declare that they have no conflict of interest.

Transparency: The authors confirm that the manuscript is an honest, accurate, and transparent account of the study was reported; that no vital features of the study have been omitted; and that any discrepancies from the study as planned have been explained.

Ethical: This study followed all ethical practices during writing.

\section{Contents}

1. Introduction 18

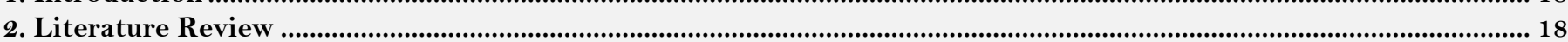

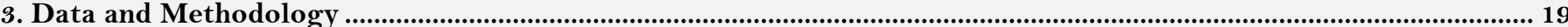

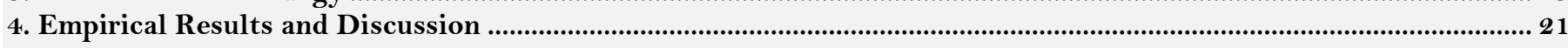

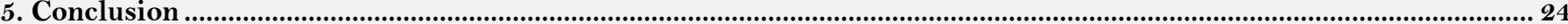

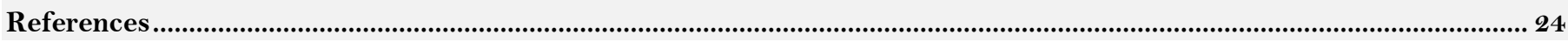




\section{Contribution of this paper to the literature}

This study contributes to the existing literature on the comparison of performance and risk of Islamic and conventional indices by combining the two aspects (performance and risk) using measures of performance (Sharpe ratio, Treynor ratio and Jensen's alpha) and risk (VaR and CVaR).

\section{Introduction}

Islamic finance has had great success in the global market. It has provided a wide range of Sharia-compliant indices to enable the accelerated advancement of Sharia-compliant funds and Islamic finance. Following this success, Muslim countries have been proposing a financial model based on Sharia, the law of the Koran. In addition to adhering to the values and principles of Islamic finance, exciting profit prospects are now being offered. At the end of 2009, the rating agency Moody's estimated the size of the Islamic finance market at $\$ 950$ billion, with a rise of about $20 \%$ each year during the past three years. Presently, there are approximately three hundred Islamic financial institutions internationally in more than seventy-five nations. Within a decade, Islamic finance could capture $50 \%$ of the savings made by 1.6 billion Muslims worldwide. In fact, the Islamic financial system stands out as an alternative model of social responsibility that is more relevant and more profound than the model proposed by classical economic theories, according to several scholars such as Chapra (2016); Siddiqi (2004); Siddiqi (2014); Khan (1997); Ahmed (2007) and Visser (2019).

This remarkable growth aims to satisfy the rising demand from the Muslim community for ethical and socially responsible investment. Indeed, the Islamic financial system feeds on the moral and religious foundations derived from the sacred book (the Koran) and the principles of Sharia law. It is based on the following five principles: (i) the prohibition of interest (riba) and usury, (ii) taking a share of the profits and losses (musharakah), (iii) forbidding uncertainty (gharar) regarding sales, and speculation (maysir); (iv) the obligation to match financial income to actual assets; and (v) the prohibition of illegal (haram) products and sectors (Elbousty \& Oubdi, 2017).

Faced with this surge in Islamic finance, this study assesses the ability of Islamic indices to cope with financial crises, and we will evaluate whether the Islamic indices are more powerful in their returns and whether they are more stable. The key goal is to compare and evaluate the outcomes achieved by the Dow Jones World Index (DJW) and their Islamic equivalents. Initially, the comparison is made using measures of performance to see if the performance of Islamic indices surpasses that of the conventional indices (Dow Jones). Next, the Dow Jones World Index is compared with its Islamic counterparts based on cumulative risk as measured by conditional value-at-risk $(\mathrm{CVaR})$ and value-at-risk $(\mathrm{VaR})$ to judge whether Islamic indices are less risk-prone than the Dow Jones World Index (DJW).

\section{Literature Review}

Islamic entrepreneurship ${ }^{1}$ cannot be approached without reference to Islamic law (Sharia). This law, stemming from the Muslim religion, is linked to the faith, customs, legislation, and economy of the Muslim Umma (community) and guides morality (Abdullah \& Mikail, 2013; Almarri \& Meewella, 2015; Anggadwita, Ramadani, Alamanda, Ratten, \& Hashani, 2017; Carneiro-da-Cunha, Santos, Souza, Alssabak, \& Macau, 2015; Muhammad, Sairally, \& Habib, 2015; Zulkifli \& Saripuddin, 2015). In fact, all economic activities carried out in Islam are subject to Halal (lawful) and Haram (unlawful) guidelines, and therefore depend on the moral and social values that every Muslim must follow (Al Rahahleh, Bhatti, \& Misman, 2019; Khatkhatay \& Nisar, 2007; Naveed, Khawaja, \& Maroof, 2020). This means that the accumulation of wealth should be a secondary priority because service to other human beings is the main priority and contributes to spiritual wellbeing (Abdullah, Kedah, \& Anwar, 2015; Ashraf, 2019; Ghoul, 2015). Salma (2013) stressed through his study of a sample of 46 institutions which offer Islamic financial services (IIFS), that these must be Sharia-compliant in addition to taking on traditional responsibilities (organizational, economic, legal and ethical) in accordance with the Sharia way of fostering society's health. Consequently, an Islamic business owner has to invest in commercial activities in line with the Muslim Act standards (Anggadwita et al., 2017; Gümüsay, 2015; Hamid \& Sa'ari, 2011; Ramadani, Dana, Ratten, \& Tahiri, 2015). In addition, Rehan, Block, \& Fisch (2019) demonstrated a positive impact on business intentions through Islamic principles and practices, while Ramadani et al. (2015) and Ghoul (2015) highlighted the fact that Islam inspires Muslims to do business and trade. Anggadwita et al. (2017) noted that Muslim beliefs inspire its followers to be entrepreneurial, creative and dynamic, and that entrepreneurship in Islam is based on cooperation. Gray, Foster, \& Howard (2006) explain that an Islamic entrepreneur should be diligent and have management expertise and skills. In Islam, work is considered a religious activity within a society because it could help the community by enhancing people's feeling of wellbeing (Anggadwita et al., 2017; Ghoul, 2015; Ramadani et al., 2015; Ratten et al., 2017). Anggadwita, Mulyaningsih, Ramadani, \& Arwiyah (2015) also stress that female entrepreneurship must be facilitated, in particular, by an appropriate Islamic education to take advantage of the opportunities offered by Allah because this has a positive impact on improving and supporting the household, women's independence and selfrealization, and therefore supports the national economy.

Over the past three decades, Sharia finance experienced the most rapid and unusual developments in the recent history of global financial services, and has moved from a niche position in the global financial system to one of the most dynamic and promising positions (Ahmed, 2002; Khan \& Bhatti, 2008). Currently, Islamic financial institutions are expanding internationally and are not exclusive to the Muslim world, but are starting to expand into Europe and the United States to capture some of the abundant liquidity from the Persian Gulf regions induced by the sharp rise in oil prices (Ghoul, 2011).

In contrast to traditional stock markets, the Islamic stock market is one in which Sharia-compliant stocks are traded (Hashim, Habib, Isaacs, \& Gadhoum, 2017). The main difference between these two modes of financing is that Islamic investment is based on fundamental Islamic principles prohibiting speculation (maysir), interest, 
excessive uncertainty, investments in industries deemed "unethical", and risk and return sharing (Zahari, Kamidjantono, \& Idham, 2009).

Islamic indices following Sharia principles are subject to different criteria for selecting liquidity and financial ratios (El Alaoui, Bacha, Masih, \& Asutay, 2016; Hakim \& Rashidian, 2002). For this reason, Islamic finance has attracted much attention in recent decades (Ahmed, 2019; Hkiri, Hammoudeh, Aloui, \& Yarovaya, 2017; Jawadi, Jawadi, \& Louhichi, 2014; Medhioub \& Chaffai, 2016).

However, profitability and risk are essential tools for measuring the attractiveness of an investment. It is also a critical determinant of performance that investors focus on during financial crises. Investments in classical and Islamic indices have been profitable, but the profits of Islamic banks are much higher than those of conventional banks (Chowdhury, 2015). Several researchers have conducted studies on the financial performance of Islamic indices and conventional indices. However, in recent years, several researchers have conducted empirical studies on the performance and risk of Islamic stock market indices. Some of these studies, such as that by Atta (2000) who studied the DJIMI (Dow Jones Islamic Market Index), concluded that the Islamic stock index outperforms its conventional counterpart as well as generating a higher return than the conventional index.

Ahmad \& Ibrahim (2002) compared the KLSI (Kuala Lumpur Shariah Index) with the Kuala Lumpur Composite Index (KCLI) utilizing the Sharpe ratio, the Treynor ratio, the balanced Jensen index, and a t-test for the period from 1999 until 2002. The outcomes showed that the KLSI yield was lower than that of the KLCI, while, regarding risk, the KLCI was riskier than the KLSI over the selected period.

This last finding was shared by Hussein (2004) who made a correlation between the presentation of the FTSE Global Islamic Index and the FTSE All-World Index. The presentation results were supportive of the Islamic index, which was higher than its conventional counterpart. Likewise, Hussein \& Omran (2005) investigated the performance of the Dow Jones Islamic Market Index (DJIMI). They observed that Islamic indices beat their regular counterparts in positively trending markets, but were less fruitful in bear markets. Yusof (2007) concentrated their investigation on the Islamic index in Malaysia, and the outcomes show a higher instability of Islamic indices compared with their conventional counterparts. At the same time, Al-Zoubi \& Maghyereh (2007) analyzed the relative risk by contrasting the risk of the Dow Jones Islamic list with that of the Dow Jones World list from 1996 to 2005. The outcomes show that the degree of risk of the Islamic index is lower than the rest of the market. In addition, the Kuala Lumpur Shariah Index (KLSI) and the Kuala Lumpur Composite Index (KLSI) were studied by Albaity \& Ahmad (2008), and the findings showed that Islamic metrics were less effective than traditional metrics.

Hassan \& Girard (2010) studied the performance of the Dow Jones Islamic Index and conventional index series and concluded that the results were not statistically different.

Mehmood (2016) studied the performance in eight countries of Islamic and conventional indices and found that, over the period as a whole, conventional stock indices outperformed Islamic indices. However, Islamic stock markets outperformed their peers during the global financial crisis period, with both adjusted and unadjusted performance measures. In addition, El Alaoui et al. (2016) found, in seven European countries with a sample of 689 firms from the second quarter of 2008 to the first quarter of 2013, that Sharia-compliant stocks have a lower market risk than conventional stocks.

Elbousty \& Oubdi (2017) compared the returns and volatility of Islamic stock indices to their conventional counterparts in developed and emerging countries from 2002 to 2016. Islamic indices outperform conventional indices in $80 \%$ of developed countries, and Islamic indices outperform conventional indices in 14 emerging market countries, according to their findings.

Rejeb \& Arfaoui (2019) attempted to confirm whether Islamic market indices outperform conventional market indices in both representational efficiency and degree of risk during recent financial stress using a GARCH(1,1) model. Their experimental findings demonstrate that the Islamic market indices exhibit high volatility and cannot avoid financial crises.

On the basis of the literature review, in spite of the abundance of past academic work evaluating the comparison of performance and risks of Islamic and conventional indices, the findings differ greatly and are not conclusive regarding the superiority of one over the other to date. Following a similar line of research, this work combines the two aspects (performance and risk) using measures of performance (Sharpe ratio, Treynor ratio and Jensen's alpha) and risk (VaR and CVaR).

\section{Data and Methodology}

\subsection{Data}

The database used contains both historical and real-time financial information, which allows us to obtain the daily prices of the various indices analyzed during the period from April 1, 2010, to April 15, 2020.

The Dow Jones Index family was selected because access to data for other indices is limited, especially Islamic indices.

For the analysis, the global indices considered are the Dow Jones World Index and its Islamic counterparts: the Dow Jones Islamic Market US Mid-Cap Index (IMUSM), the Dow Jones Islamic Market World Index (DJIM), the Islamic Market Asia/Pacific Index (DJIAP), the Dow Jones Islamic Market World Emerging Markets Index (DJIEMG), the Dow Jones Islamic Market Malaysia Index (DJMY25), and the Dow Jones Islamic Market Turkey Index (DJIMTR).

The Dow Jones Islamic Market World Index is the equivalent index to the DJW, but it satisfies the principles of Sharia. Each company included in the Islamic index must comply with several requirements, including the type of product offered, economic activity, and the level of debt.

\subsection{Methodology}

There is a difference in the performance and risks of Islamic indices and their traditional equivalents, as noted during the review of existing literature on this topic. A hypothetical-deductive quantitative analysis was chosen, which is one of the models used for scientific reasoning and research (Tariq, 2015). In the context of this work, this 
approach is used to show whether the output of Islamic indices exceeds that of traditional indices and to demonstrate whether the overall risk of Islamic indices is lower than that of conventional indices. However, the holistic-inductive qualitative approach is an alternative to validating these methods that have arisen in exploratory research to gain a global understanding of investors and their behaviours (Dana \& Dana, 2005). To complement the numerous quantitative studies in management and, more specifically, in entrepreneurship, Dana \& Dana (2005) promote more qualitative research with inductive holistic conceptions to generate new hypotheses to help formulate better policies for the future. This research is exploratory and descriptive in nature. First, in order to analyze and compare the performance of Islamic indices with their conventional equivalents, we use financial performance measures (the Sharpe ratio, the Treynor ratio and Jensen's alpha). In the second step, value-at-risk $(\mathrm{VaR})$ and conditional value-at-risk (CVR) are used to compare the total risk of such indices $(\mathrm{CVaR})$.

\subsection{Performance Measures}

To assess the performance of the Dow Jones World Index and its Islamic counterparts, this study looks at the return and instability qualities of each index alongside the risk-adjusted returns. To estimate the risk-adjusted performance of the DJW and its Islamic counterparts, the Agouram \& Lakhnati (2016) methodology was used to establish a ranking of the different indices. Performance measures that are used to compare our indices are:

- The Sharpe ratio: This calculates the excess return of the portfolio compared to the risk-free investment, but only relates to the volatility that negatively affects the asset.

$$
S_{p}=\frac{E\left(R_{p}\right)-r_{f}}{\sigma_{\left(R_{p}\right)}}(1)
$$

Where $E\left(R_{p}\right)$ is the expected portfolio return, $\sigma_{\left(R_{p}\right)}$ is the portfolio standard deviation, and $r_{f}$ is the risk-free return (in Equation 1).

- Treynor ratio: This indicates the risk premium per unit of systematic risk. The Treynor ratio is calculated as:

$$
\mathrm{T}_{\mathrm{p}}=\frac{\mathrm{E}\left(\mathrm{R}_{\mathrm{p}}\right)-\mathrm{r}_{\mathrm{f}}}{\beta_{\mathrm{p}}}(2)
$$

Where $\beta_{\mathrm{p}}$ in Equation 2 is the beta of the portfolio.

- Jensen's alpha: To see exactly how the formula of Jensen's alpha works, let's look at the CAPM formula (in Equation 3):

Jensen's alpha value is calculated as follows:

$$
E\left(R_{p}\right)=r_{f}+\beta_{p}\left(E\left(R_{m}\right)-r_{f}\right)+\alpha
$$

$$
\alpha=E\left(R_{p}\right)-\left(r_{f}+\beta_{p}\left(E\left(R_{m}\right)-r_{f}\right)\right.
$$

Where $E\left(R_{m}\right)$ is the expected market return (in Equation 4 ).

To make a comparison over the entire period chosen, performance measures are calculated for each month using the Borda-Kendall (BK) method, which has been used to establish a portfolio classification. The strategy of the BK method provides a primary location label of "1", a second position label of "2", etc. With this simple equation, the rating scale $(\mathrm{Zi})$ that each portfolio collects can be obtained:

$$
\mathrm{Z}_{\mathrm{i}}=\sum_{\mathrm{i}=1}^{\mathrm{p}} \mathrm{j} \mathrm{v}_{\mathrm{ij}}
$$

Where $\mathrm{j}$ is the rank and $\mathrm{v}_{\mathrm{ij}}$ is the vote; each investment is ranked in a $\mathrm{j}^{\mathrm{th}}$ ranking place. The best possible asset allocation would be the one with the lowest overall score (in Equation 5).

\subsubsection{Risk Measures}

In order to compare indices ${ }^{2}$, the value-at-risk $(\mathrm{VaR})$ is used, taking into account the essential characteristics of asset returns (i.e., the profit pattern of the group in high and low unpredictability bundles with a non-typical circulation of profits, overwhelming tails, and a negative predisposition).

In the VaR forecast for each index, the following elements are included:

- Initially, the $\operatorname{GARCH}(1,1)$ model is used to analyze the VaR's sensitivity to the yield distribution's characteristics (the variance that varies over time) by assuming that the portfolio's yield follows the normal distribution.

- Second, the VaR of each portfolio is numerically calculated based on the Cornish-Fisher expansion (CF) and Johnson's distribution using moments to adjust for long queues and skewness in VaR predictions.

- Last, the conditional value-at-risk (CVaR) is used to compare the indices because the results are similar to $\mathrm{VaR}$. The $\mathrm{CVaR}$ is able to take a much better appreciation of the queue risk.

The VaR associated with risk $\mathrm{X}$ is given by Equation 6:

$$
\operatorname{VaR}(X)=\inf \{x \mid P[X \leq x]\}
$$

The CVaR at the probability level, denoted by CVaR (X), is the average value of the losses that exceed the VaR with a given confidence level. Equation 7 gives us the following formula:

The use of the data is as follows:

$$
\operatorname{CVaR}(X)=E[X \mid X<\operatorname{VaR}(X)]
$$

(a) For performance measures: The entire period is used to calculate index performance using three performance measures: the Sharpe ratio, the Treynor ratio, and Jensen's alpha, in addition to the two summary statistics: mean return and standard deviation.

(b) For the calculation of the VaR of the indices: The first 2170 daily returns are used, that correspond to the period from April 1, 2010, to June 3, 2018, for the estimation of volatility using the $\operatorname{GARCH}(1,1)$ model. Second, the VaR is estimated by one day $(h=1)$ for risk levels $(\mathrm{a}=1 \%, 5 \%$, and $10 \%)$ over the period from June 4, 2018, to

2 As in Agouram \& Lakhnati (2015a); Agouram \& Lakhnati (2015b). 
April 15, 2020 (720 values) using the $\operatorname{GARCH}(1,1)$ estimators. The estimated VaRs and the losses actually observed will be compared using a backtesting procedure.

\section{Empirical Results and Discussion}

This empirical analysis started with characteristics of the chosen indexes. We define the tests and the coefficients that allow the detection of the normality of the series, and then an investigation is carried out on the distribution of the series studied.

(a) Study of the normality of returns: For a long time, the behavior of the profitability series of financial securities was considered normal. However, in reality, several empirical studies have shown that these series are non-normal. Their distributions are, on the contrary, asymmetrical, and display leptokurtosis, meaning that they are often thicker at the ends and reveal thick tails. The normality of the returns is checked by econometric tests, which are based on the determination of symmetry coefficients (skewness) and flattening (kurtosis). One of these tests is the Jarque-Bera statistic that synthesizes the two coefficients. The Jarque-Bera test is based on skewness coefficients and kurtosis, and it evaluates the simultaneous deviations of these coefficients with the reference values of normal distribution.

Table 1. Descriptive statistics of indices.

\begin{tabular}{l|c|c|c|c|c|c|c}
\hline & DJIAP & DJIEMG & DJIM & DJIMTR & DJMY25 & IMUSM & INDU \\
\hline Mean & 0.034 & 0.030 & 0.036 & 0.052 & 0.021 & 0.060 & 0.047 \\
\hline Median & 0.000 & 0.000 & 0.000 & 0.000 & 0.000 & 0.000 & 0.000 \\
\hline Maximum & 4.208 & 5.158 & 4.260 & 5.390 & 2.910 & 5.723 & 4.985 \\
\hline Minimum & -4.568 & -6.082 & -5.148 & -7.899 & -3.294 & -7.398 & -5.546 \\
\hline Std. Dev. & 0.827 & 0.847 & 0.745 & 1.046 & 0.551 & 1.014 & 0.855 \\
\hline Skewness & -0.275 & -0.175 & -0.347 & -0.469 & -0.145 & -0.286 & -0.319 \\
\hline Kurtosis & 6.212 & 8.175 & 8.856 & 7.390 & 7.207 & 7.877 & 7.446 \\
\hline Jarque-Bera test & 1283 & 3252 & 4203 & 2435 & 2149 & 2915 & 2438 \\
\hline Probability & 0.000 & 0.000 & 0.000 & 0.000 & 0.000 & 0.000 & 0.000 \\
\hline Sum & 99.634 & 87.433 & 103.014 & 150.382 & 60.877 & 175.389 & 136.018 \\
\hline Observations & 2901 & 2901 & 2901 & 2901 & 2901 & 2901 & 2901 \\
\hline
\end{tabular}

(b) Empirical results: Using the Jarque-Bera test on normality, it was found that the distribution of the returns of the indices does not follow the normal distribution and is at a threshold of $a=1 \%$. The values of the Jarque-Bera statistics for each title are given in Table 1 . They all exceed the critical value of the test, which is 9, and 83 for the threshold of a $=1 \%$. The results obtained from the table above show that the skewness coefficient is negative for all indices, which means that the left side of their distributions are thick (negative direction). Thus, the existence of asymmetrical behavior of the series of yields is studied, while the kurtosis coefficient results are greater than 3, which means that the tails are thicker than the normal law (leptokurtic distribution). As a result, the outcomes of the test of normality (Jarque-Bera) for each index lead us to exclude assumption of normality at a 99\% degree of probability. This finding highlighted the very familiar properties of a series of financial returns, i.e., the returns of the various series are not distributed normally (Agouram \& Lakhnati, 2015a, 2015b). In combination, the properties of asymmetry and leptocurticity were found to be true for the data. The index returns appear in Figure 1.

\subsection{Performance Measures}

Table 2. Comparison of returns.

\begin{tabular}{|c|c|c|c|c|c|c|c|}
\hline & \multicolumn{6}{|c|}{ Indices } & \multirow{2}{*}{ DJW } \\
\hline & IMUSM & DJIM & DJIAP & DJIEMG & DJMY25 & DJIMTR & \\
\hline Borda points & 161 & 545 & 540 & 546 & 678 & 254 & 440 \\
\hline Rank & 1 & 5 & 4 & 6 & 7 & 2 & 3 \\
\hline Average rank & 1.42 & 4.82 & 4.77 & 4.83 & 6 & 2.24 & 3.89 \\
\hline
\end{tabular}

The monthly return rate results for the entire sampling period (see Table 2) show that the IMUSM score is the lowest based on the 161-point Borda-Kendall approach, followed in second place by the DJIMTR with 254 points. The DJW is third with 440 points, and the DJMY25 index is in last place with a score of 678 points.

Table 3. Comparison of volatilities.

\begin{tabular}{l|c|c|c|c|c|c|c|c}
\hline & \multicolumn{7}{|c|}{ Indices } & \multirow{2}{*}{ DJW } \\
\cline { 2 - 10 } & IMUSM & DJIM & DJIAP & DJIEMG & DJMY25 & DJIMTR & DJW \\
\hline Borda points & 776 & 226 & 429 & 592 & 113 & 653 & 375 \\
\hline Rank & 7 & 2 & 4 & 5 & 1 & 6 & 3 \\
\hline Average rank & 6.87 & 2 & 3.8 & 5.24 & 1 & 5.78 & 3.32 \\
\hline
\end{tabular}

The results in Table 3 are different from those related to rates of return. The least risky index is the DJMY25, with 113 points for the entire period, followed by the DJIM index, while the DJW comes in third place. 

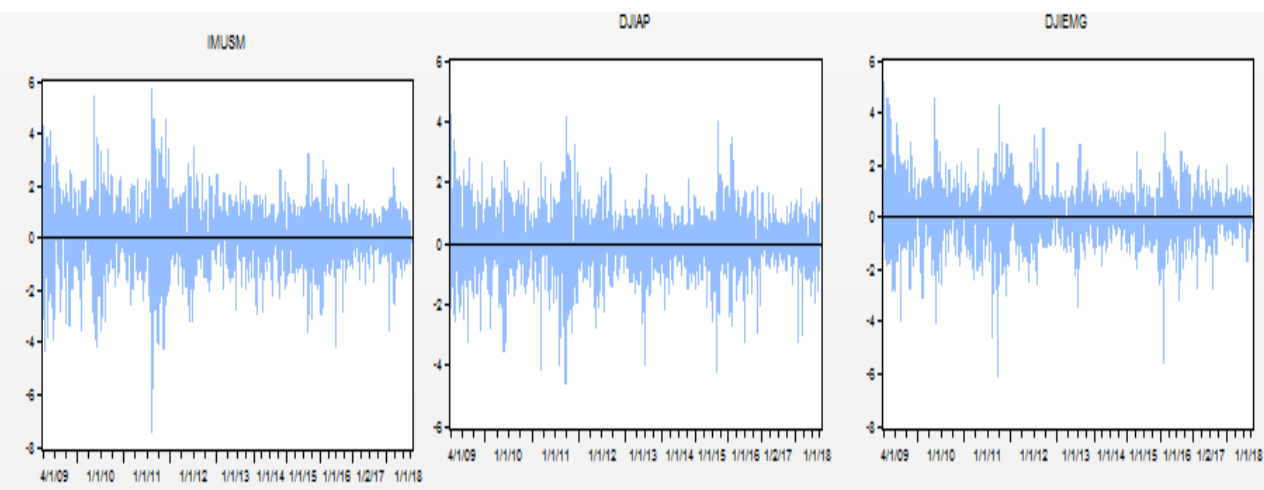

DMM
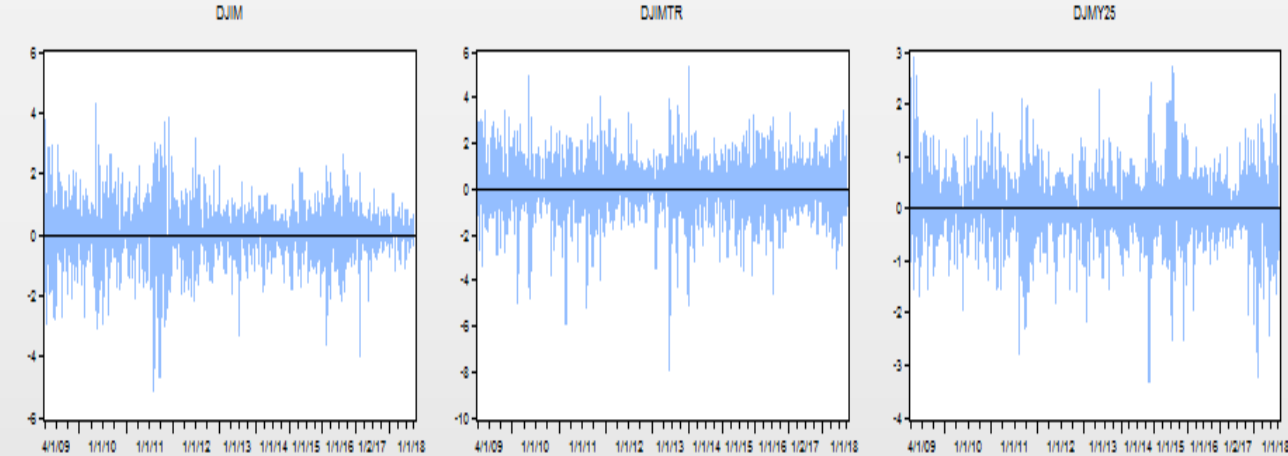

DN

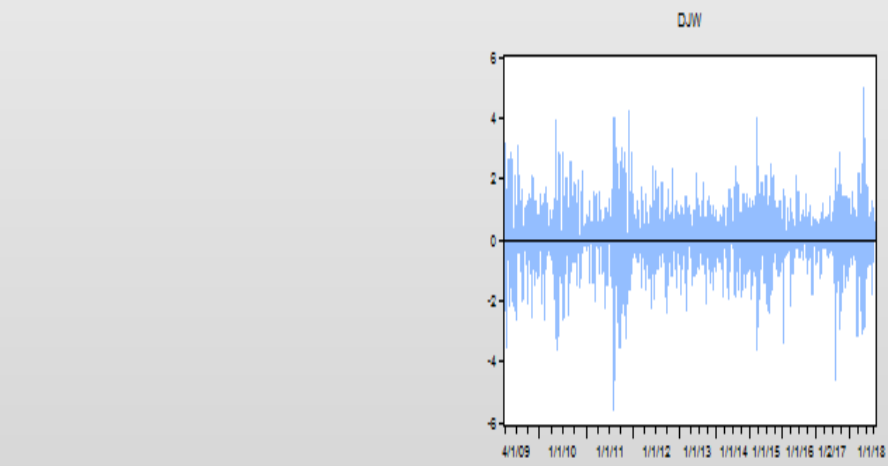

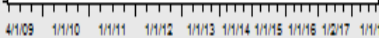

Figure 1. Graphical representation of index returns.

Table 4. Performance comparison: Sharpe ratio.

\begin{tabular}{l|c|c|c|c|c|c|c}
\hline & \multicolumn{9}{|c}{ Indices } & \multirow{2}{*}{ DJW } \\
\cline { 2 - 8 } & IMUSM & DJIM & DJIAP & DJIEMG & DJMY25 & DJIMTR & \\
\hline Borda points & 246 & 572 & 567 & 619 & 399 & 316 & 445 \\
\hline Rank & 1 & 6 & 5 & 7 & 3 & 2 & 4 \\
\hline Average rank & 2.18 & 5.06 & 5.02 & 5.48 & 3.53 & 2.8 & 3.94 \\
\hline
\end{tabular}

From the results of the Sharpe ratio in Table 4, we can see that IMUSM has the highest score with 246 points, followed in second place by the DJIMTR with score of 316 points, while the DJW comes in fifth place.

Table 5. Performance comparison: Treynor ratio.

\begin{tabular}{|c|c|c|c|c|c|c|c|}
\hline & \multicolumn{6}{|c|}{ Indices } & \multirow{2}{*}{ DJW } \\
\hline & IMUSM & DJIM & DJIAP & DJIEMG & DJMY25 & DJIMTR & \\
\hline Borda points & 378 & 720 & 465 & 692 & 249 & 190 & 470 \\
\hline Rank & 3 & 7 & 4 & 6 & 2 & 1 & 5 \\
\hline Average rank & 3.35 & 6.37 & 4.12 & 6.12 & 2.2 & 1.68 & 4.16 \\
\hline
\end{tabular}

From the results in Table 5, the DJIMTR index is the best out of all indices evaluated with a score of 190 points, followed by the DJMY25 with a score of 249 points, while the DJW index occupies the sixth place with a score of 470 points.

Table 6. Performance comparison: Jensen's alpha.

\begin{tabular}{|c|c|c|c|c|c|c|c|}
\hline & \multicolumn{6}{|c|}{ Indices } & \multirow{2}{*}{ DJW } \\
\hline & IMUSM & DJIM & DJIAP & DJIEMG & DJMY25 & DJIMTR & \\
\hline Borda points & 219 & 720 & 441 & 679 & 466 & 195 & 444 \\
\hline Rank & 2 & 7 & 3 & 6 & 5 & 1 & 4 \\
\hline Average rank & 1.94 & 6.37 & 3.9 & 6.01 & 4.12 & 1.73 & 3.93 \\
\hline
\end{tabular}

The outcomes of Jensen's alpha scoring in Table 6 show that the DJIMTR index is the highest of all indices, second is the IMUSM, followed by the DJIAP. Since the classification of the indices results differ for each calculation, we have plotted the various classifications of indices for all the measures used in Figure 1. Figure 2 provides an overview of the seven indices' ranks. 


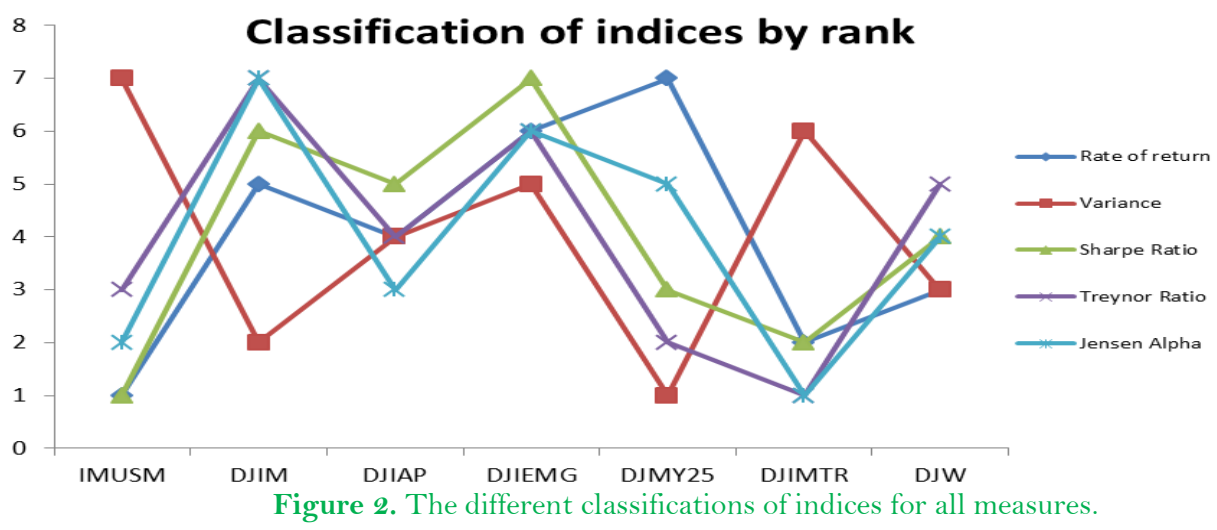

\subsection{Risk Measures}

The evaluation of different forecasting methods is based on various statistical tests, such as unconditional coverage tests, independence tests, and conditional coverage tests. The results of the unconditional coverage test proposed by Kupiec (1995) show that for the $\operatorname{VaR} \operatorname{GARCH}(1,1)$ with the normal distribution, the Cornish-Fisher approximation and the Johnson function, we find that the $\operatorname{GARCH}(1,1)$ models in our study are appropriate for the prediction of the VaR for the critical values of $1 \%, 5 \%$ and $10 \%$, and the tests are valid for the estimation of VaR (Tables 7, 8 and 9). In general, it was found that the VaR overruns for the conventional index are positioned between the Islamic indices. Thus, the conventional index is less risky than some Islamic indices and riskier than the others for the 99\%,95\% and 90\% confidence levels and with the different estimation methods (normal distribution, Cornish-Fisher approximation and Johnson function - see Tables 10, 11 and 12).

Table 7. Results of conditional and unconditional VaR coverage using the normal distribution

\begin{tabular}{|c|c|c|c|c|c|c|c|c|}
\hline $\begin{array}{c}\text { Confidence } \\
\text { level }\end{array}$ & & IMUSM & DJIM & DJIAP & DJIEMG & DJMY25 & DJIMTR & DJW \\
\hline \multirow[b]{5}{*}{$1 \%$} & $\mathrm{~N}$ & 5 & 4 & 5 & 5 & 3 & 8 & 7 \\
\hline & TAUX & 0.007 & 0.006 & 0.007 & 0.007 & 0.004 & 0.011 & 0.010 \\
\hline & Lruc & 0.748 & 1.694 & 0.748 & 0.748 & 3.148 & 0.091 & 0.005 \\
\hline & LRIND & 5.936 & $\mathrm{~N} / \mathrm{A}$ & $\mathrm{N} / \mathrm{A}$ & $\mathrm{N} / \mathrm{A}$ & $\mathrm{N} / \mathrm{A}$ & $\mathrm{N} / \mathrm{A}$ & 3.774 \\
\hline & LR CC & 6.685 & $\mathrm{~N} / \mathrm{A}$ & $\mathrm{N} / \mathrm{A}$ & $\mathrm{N} / \mathrm{A}$ & $\mathrm{N} / \mathrm{A}$ & $\mathrm{N} / \mathrm{A}$ & 3.779 \\
\hline \multirow[b]{5}{*}{$5 \%$} & $\mathrm{~N}$ & 13 & 9 & 17 & 15 & 7 & 26 & 19 \\
\hline & TAUX & 0.018 & 0.013 & 0.024 & 0.021 & 0.010 & 0.036 & 0.026 \\
\hline & Lruc & 20.150 & 29.944 & 12.903 & 16.253 & 36.120 & 3.166 & 10.036 \\
\hline & LRIND & 31.198 & 32.718 & 13.572 & 17.267 & $\mathrm{~N} / \mathrm{A}$ & 9.414 & 16.475 \\
\hline & LR CC & 51.347 & 62.662 & 26.475 & 33.520 & $\mathrm{~N} / \mathrm{A}$ & 12.580 & 26.511 \\
\hline \multirow[b]{5}{*}{$10 \%$} & $\mathrm{~N}$ & 29 & 20 & 27 & 27 & 14 & 59 & 32 \\
\hline & TAUX & 0.040 & 0.028 & 0.038 & 0.038 & 0.019 & 0.082 & 0.045 \\
\hline & Lruc & 20.150 & 29.944 & 12.903 & 16.253 & 36.120 & 3.166 & 10.036 \\
\hline & LRIND & 31.198 & 32.718 & 13.572 & 17.267 & $\mathrm{~N} / \mathrm{A}$ & 9.414 & 16.475 \\
\hline & LR CC & 51.347 & 62.662 & 26.475 & 33.520 & $\mathrm{~N} / \mathrm{A}$ & 12.580 & 26.511 \\
\hline
\end{tabular}

Table 8. Results of conditional and unconditional VaR coverage using the Cornish-Fisher approach.

\begin{tabular}{|c|c|c|c|c|c|c|c|c|}
\hline $\begin{array}{c}\text { Confidence } \\
\text { level }\end{array}$ & & IMUSM & DJIM & DJIAP & DJIEMG & DJMY25 & DJIMTR & DJW \\
\hline \multirow[b]{5}{*}{$1 \%$} & $\mathrm{~N}$ & 3 & 3 & 3 & 3 & 1 & 3 & 3 \\
\hline & TAUX & 0.004 & 0.004 & 0.004 & 0.004 & 0.001 & 0.004 & 0.004 \\
\hline & Lruc & 3.148 & 3.148 & 3.148 & 3.148 & 8.471 & 3.148 & 3.148 \\
\hline & LRIND & $\mathrm{N} / \mathrm{A}$ & $\mathrm{N} / \mathrm{A}$ & $\mathrm{N} / \mathrm{A}$ & $\mathrm{N} / \mathrm{A}$ & $\mathrm{N} / \mathrm{A}$ & $\mathrm{N} / \mathrm{A}$ & $\mathrm{N} / \mathrm{A}$ \\
\hline & LR CC & $\mathrm{N} / \mathrm{A}$ & $\mathrm{N} / \mathrm{A}$ & $\mathrm{N} / \mathrm{A}$ & $\mathrm{N} / \mathrm{A}$ & $\mathrm{N} / \mathrm{A}$ & $\mathrm{N} / \mathrm{A}$ & $\mathrm{N} / \mathrm{A}$ \\
\hline \multirow[b]{5}{*}{$5 \%$} & $\mathrm{~N}$ & 20 & 11 & 20 & 20 & 8 & 37 & 25 \\
\hline & TAUX & 0.028 & 0.015 & 0.028 & 0.028 & 0.011 & 0.052 & 0.035 \\
\hline & Lruc & 8.768 & 24.676 & 8.768 & 8.768 & 32.905 & 0.035 & 3.880 \\
\hline & LRIND & 18.968 & 26.706 & 9.072 & 9.072 & $\mathrm{~N} / \mathrm{A}$ & 2.038 & 10.685 \\
\hline & LR CC & 27.736 & 51.382 & 17.840 & 17.840 & $\mathrm{~N} / \mathrm{A}$ & 2.073 & 14.565 \\
\hline \multirow[b]{5}{*}{$10 \%$} & $\mathrm{~N}$ & 59 & 37 & 49 & 51 & 30 & 86 & 48 \\
\hline & TAUX & 0.082 & 0.052 & 0.068 & 0.071 & 0.042 & 0.120 & 0.067 \\
\hline & Lruc & 2.683 & 22.382 & 8.953 & 7.372 & 33.886 & 2.755 & 9.808 \\
\hline & LRIND & 4.783 & 24.384 & 10.982 & 7.924 & 41.271 & 7.904 & 24.309 \\
\hline & LR CC & 7.466 & 46.766 & 19.935 & 15.297 & 75.158 & 10.659 & 34.117 \\
\hline
\end{tabular}

In contrast to the VaR results, the CVaR results show that the DJW index has lower and stronger CVaRs compared to its Islamic counterparts.

Based on these results, the DJW index is not better in terms of risk since it records higher levels in terms of CVaR at the $99 \%, 95 \%$ and $90 \%$ confidence levels, that is to say, this case study shows that the DJW does not provide the best possible coverage against the downside risks of the market in comparison to some Islamic indices that are less risky. 
Table 9. Results of conditional and unconditional VaR coverage using the Johnson function.

\begin{tabular}{|c|c|c|c|c|c|c|c|c|}
\hline Confidence level & & IMUSM & DJIM & DJIAP & DJIEMG & DJMY25 & DJIMTR & DJW \\
\hline \multirow{5}{*}{$1 \%$} & $\mathrm{~N}$ & 7 & 6 & 8 & 10 & 4 & 14 & 14 \\
\hline & TAUX & 0.010 & 0.008 & 0.011 & 0.014 & 0.006 & 0.019 & 0.019 \\
\hline & Lruc & 0.007 & 0.008 & 0.010 & 0.014 & 0.006 & 0.018 & 0.017 \\
\hline & LRIND & 0.286 & 0.000 & 0.125 & 0.000 & 0.000 & 0.071 & 0.143 \\
\hline & LR CC & 0.714 & 1.000 & 0.875 & 1.000 & 1.000 & 0.929 & 0.857 \\
\hline \multirow{5}{*}{$5 \%$} & $\mathrm{~N}$ & 28 & 16 & 27 & 24 & 12 & 50 & 30 \\
\hline & TAUX & 0.039 & 0.022 & 0.038 & 0.033 & 0.017 & 0.070 & 0.042 \\
\hline & Lruc & 1.973 & 14.514 & 2.531 & 4.678 & 22.328 & 4.875 & 1.078 \\
\hline & LRIND & 0.179 & 0.063 & 0.074 & 0.042 & 0.083 & 0.101 & 0.133 \\
\hline & LR CC & 0.821 & 0.938 & 0.926 & 0.958 & 0.917 & 0.899 & 0.867 \\
\hline \multirow{5}{*}{$10 \%$} & $\mathrm{~N}$ & 59 & 36 & 47 & 47 & 29 & 84 & 44 \\
\hline & TAUX & 0.082 & 0.050 & 0.065 & 0.065 & 0.040 & 0.117 & 0.061 \\
\hline & Lruc & 0.077 & 0.047 & 0.061 & 0.064 & 0.035 & 0.106 & 0.049 \\
\hline & LRIND & 0.136 & 0.111 & 0.128 & 0.085 & 0.172 & 0.192 & 0.250 \\
\hline & LR CC & 0.864 & 0.889 & 0.872 & 0.915 & 0.828 & 0.808 & 0.750 \\
\hline
\end{tabular}

Table 10. CVaR results of the VaR GARCH(1,1) model with normal distribution.

\begin{tabular}{c|c|c|c|c|c|c|c}
\hline Confidence level & IMUSM & DJIM & DJIAP & DJIEMG & DJMY25 & DJIMTR & DJW \\
\hline $1 \%$ & -2.26 & -2.23 & -2.3 & -2.2 & -2.18 & -2.38 & -2.33 \\
\hline $5 \%$ & -1.61 & -1.58 & -1.61 & -1.59 & -1.73 & -1.79 & -1.66 \\
\hline $10 \%$ & -1.39 & -1.28 & -1.39 & -1.3 & -1.27 & -1.38 & -1.33 \\
\hline
\end{tabular}

Table 11. CVaR results of the VaR GARCH $(1,1)$ model with the Cornish-Fisher approach.

\begin{tabular}{c|c|c|c|c|c|c|c}
\hline Confidence level & IMUSM & DJIM & DJIAP & DJIEMG & DJMY25 & DJIMTR & DJW \\
\hline $1 \%$ & -2.57 & -2.89 & -2.89 & -2.69 & -2.69 & -3.46 & -2.74 \\
\hline $5 \%$ & -1.54 & -1.46 & -1.5 & -1.5 & -1.52 & -1.59 & -1.55 \\
\hline $10 \%$ & -1.03 & -0.95 & -0.97 & -1 & -0.97 & -1.03 & -1.09 \\
\hline
\end{tabular}

\begin{tabular}{c|c|c|c|c|c|c|c}
\multicolumn{8}{c}{ Table 12. CVaR results of the VaR GARCH(1,1) with the Johnson function. } \\
\hline Confidence level & IMUSM & DJIM & DJIAP & DJIEMG & DJMY25 & DJIMTR & DJW \\
\hline $1 \%$ & -2 & -2 & -1.95 & -1.87 & -1.89 & -2.05 & -2.07 \\
\hline $5 \%$ & -1.08 & -1 & -0.99 & -1.02 & -1.01 & -1.07 & -1.01 \\
\hline $10 \%$ & -1.07 & -0.99 & -1.01 & -1.04 & -1 & -1.07 & -1.11 \\
\hline
\end{tabular}

\section{Conclusion}

Islamic investors all have a common desire to find investment opportunities that are compatible with their convictions, commitments, and moral values. Ramadani et al. (2015) noted that entrepreneurship and Islamic affairs will become increasingly important with globalization in the future. These entrepreneurs will, therefore, be led to make investments in assets compatible with Sharia or simply on Islamic indices.

This article adds to the area of Islamic business by supporting discussions from past research on the performance and risk of Islamic indices, especially in the context of investment in international indexes (Ahmad \& Ibrahim, 2002; Atta, 2000; Elbousty \& Oubdi, 2017; Hussein, 2004; Hussein \& Omran, 2005). Moreover, it is only in recent years that researchers have been interested in management and management research with regard to spirituality and ethics in the workplace, among other religious ethics in the world of business and finance (Balog, Baker, \& Walker, 2014; Dana, 2010; Tracey, 2012). In addition, the findings of this study indicate the importance of Islamic index investments. Based on performance measures, some Islamic indices outperform conventional indices. Academic works differ on the outperformance or underperformance of Islamic indices. Indeed, it is the stock market indices and the Islamic investment funds, in addition to the Sukuk (financial certificate), which constitute the main tools of the offer of Islamic finance in financial markets.

The empirical application of a sample of indices to assess the contribution of performance and risk measures to the resolution of problems regarding the choice between Islamic or conventional indices allowed us to obtain the following results:

- The volatile, leptokurtic and asymmetric return sequence of our indices. This leads to a denial of the JarqueBera normality test. Therefore, the distribution of returns of regular indices varies from the normal distribution.

- The presence of volatility clusters in the different series of yields means that a crisis has severely disrupted the evolution of index prices.

- Improved performance of the value-at-risk by the use of the $\operatorname{GARCH}(1,1)$ model with Student distribution, and the Cornish-Fisher approximation for estimating the volatility and quantiles of the distribution.

- The performance of certain Islamic indices may be better than that of traditional indices. Thus, the use of an Islamic index may be better for an investor than the use of a conventional index.

- The risks of certain Islamic indices are lower than those of conventional indices; therefore, an Islamic index may be less risky than a conventional index.

Finally, the results obtained in this study confirm the relevance of investments in Islamic indices.

\section{References}

Abdullah, S., \& Mikail, S. A. (2013). Entrepreneurship and Islam: An expository study on characteristics of Muslim entrepreneur. Paper presented at the Proceeding of the 5th Islamic Economics System Conference: Sustainable Development Through The Islamic Economics System, Faculty Economics And Muamalat, UniversitiSains Islam Malaysia, Kuala Lumpur. 
Abdullah., M. A., Kedah, Z., \& Anwar, M. A. (2015). Effects of Islamic entrepreneurship mind programming on entrepreneurial performance through entrepreneurial motivation. International Journal of Business and Globalisation, 15(3), 294-312. Available at: https://doi.org/10.1504/ijbg.2015.071909.

Agouram, J., \& Lakhnati, G. (2016). Mean-Gini and mean-extended gini portfolio selection: An empirical analysis. Risk Governance \& Control: Financial Markets and Institutions, 6(3-1), 59-66. Available at: https://doi.org/10.22495/rcgv6i3c1art7.

Agouram, J., \& Lakhnati, G. (2015a). A comparative study of mean-variance and mean gini portfolio selection using VaR and CVaR. Journal of Financial Risk Management, 4(2), 72-81. Available at: https://doi.org/10.4236/jfrm.2015.42007.

Agouram, J., \& Lakhnati, G. (2015b). Mean-Gini portfolio selection: Forecasting VaR using GARCH models in Moroccan financial market. Journal of Economics and International Finance, 7(3), 51-58.

Ahmad, Z., \& Ibrahim, H. (2002). A study of performance of the KLSE Syariah index. Malaysian Management Journal, 6(1\&2), 25-34.

Ahmed, H. (2007). Waqf based microfiance: Realising the social role of Islamic Finance. Paper presented at the During the International Seminar Integrating Awqaf in the Islamic Financial Sector", 6-7 March 2007m Singapore.

Ahmed, H. (2002). A microeconomic model of an Islamic bank: The Islamic Research and Teaching Institute (IRTI)

Ahmed, W. M. (2019). Islamic and conventional equity markets: Two sides of the same coin, or not? The Quarterly Review of Economics and Finance, 72, 191-205. Available at: https://doi.org/10.1016/j.qref.2018.12.010.

Al-Zoubi, H. A., \& Maghyereh, A. I. (2007). The relative risk performance of Islamic finance: A new guide to less risky investments International Journal of Theoretical and Applied Finance, 1O(O2), 235-249. Available at: https://doi.org/10.1 142/s02 19024907004184.

Al Rahahleh, N., Bhatti, M. I., \& Misman, F. N. (2019). Developments in risk management in islamic finance: A review. Journal of Risk and Financial Management, 12(1), 1-22. Available at: https://doi.org/10.3390/jrfm12010037.

Albaity, M., \& Ahmad, R. (2008). Performance of Syariah and composite indices: Evidence from Bursa Malaysia. Asian Academy of Management Journal of Accounting and Finance, 4(1), 23-43.

Almarri, J., \& Meewella, J. (2015). Social entrepreneurship and Islamic philanthropy. International Journal of Business and Globalisation, 15(3), 405-424. Available at: https://doi.org/10.1504/ijbg.2015.071901.

Anggadwita, G., Ramadani, V., Alamanda, D. T., Ratten, V., \& Hashani, M. (2017). Entrepreneurial intentions from an Islamic perspective: A study of Muslim entrepreneurs in Indonesia. International Journal of Entrepreneurship and Small Business, 31(2), 165-179. Available at: https://doi.org/10.1504/ijesb.2017.10004845.

Anggadwita, G., Mulyaningsih, H. D., Ramadani, V., \& Arwiyah, M. Y. (2015). Women entrepreneurship in Islamic perspective: A driver for social change. International Journal of Business and Globalisation, 15(3), 389-404. Available at: https://doi.org/10.1504/ijbg.2015.071914

Ashraf, M. A. (2019). Theory of Islamic entrepreneurship: A conceptual paper. International Journal of Entrepreneurship, $23(3)$, 1-12.

Atta, H. (2000). Ethical rewards: An examination of the effect of Islamic ethical screens on financial performance and of conditioning information on performance measures. Master of Science Dissertation, University of Durham.

Balog, A. M., Baker, L. T., \& Walker, A. G. (2014). Religiosity and spirituality in entrepreneurship: A review and research agenda. Journal of Management, Spirituality \& Religion, 11(2), 159-186. Available at: https://doi.org/10.1080/14766086.2013.836127.

Carneiro-da-Cunha, J. A., Santos, M. G. D., Souza, L. J. D., Alssabak, N. A. M., \& Macau, F. R. (2015). The history of an Islamic entrepreneurship: Achieving exporting-network leadership through religious legitimacy. International Journal of Business and Globalisation, 15(3), 272-293. Available at: https://doi.org/10.1504/ijbg.2015.071921.

Chapra, M. U. (2016). The future of economics: An Islamic perspective (Vol. 21): Kube Publishing Ltd.

Chowdhury, M. A. F. (2015). Which is more important in terms of profitability of Islamic banks: Bank specific factors or macroeconomic factors? An empirical study on Malaysian Islamic Banks. European Journal of Islamic Finance, 2, 1-8. Available at: https://doi.org/10.13135/2421-2172/922.

Dana, L.-P. (2010). Entrepreneurship and religion. Cheltenham: Edward Elgar Publishing.

Dana, L. P., \& Dana, T. E. (2005). Expanding the scope of methodologies used in entrepreneurship research. International Journal of Entrepreneurship and Small Business, 2(1), 79-88. Available at: https://doi.org/10.1504/ijesb.2005.006071.

El Alaoui, A. O., Bacha, O. I., Masih, M., \& Asutay, M. (2016). Shari'ah screening, market risk and contagion: A multi-country analysis. Journal of Economic Behavior \& Organization, 132, 93-1 12. Available at: https://doi.org/10.1016/j.jebo.2016.10.023.

Elbousty, M. D., \& Oubdi, L. (2017). Are islamic stock indices better than their conventional counterparts? -Comparative study between emerging and developed countries. Research and Applications in Islamic Finance (RAFI), 1(2), 100-120.

Ghoul, W. A. (2015). Entrepreneurship within the framework of Shari'ah. International Journal of Business and Globalisation, 15(3), 262-271.

Ghoul, A. W. (2011). Islam and entrepreneurship. In Dana, L-P. (Ed.), World Encyclopedia of Entrepreneurship (pp. 293-301). Cheltenham: Edward Elgar Publishing.

Gray, K. R., Foster, H., \& Howard, M. (2006). Motivations of moroccans to be entrepreneurs. Journal of Developmental Entrepreneurship, $11(4)$, 297-318. Available at: https://doi.org/10.1142/s1084946706000507.

Gümüsay, A. A. (2015). Entrepreneurship from an Islamic perspective. Journal of Business Ethics, 130(1), 199-208. Available at: https://doi.org/10.1007/s 10551-014-2223-7.

Hakim, S., \& Rashidian, M. (2002). Risk and return of Islamic stock market indexes. Paper presented at the 9th Economic Research Forum Annual Conference in Sharjah, UAE.

Hamid, S. A., \& Sa'ari, C. Z. (2011). Reconstructing entrepreneur's development based on al-Qur'an and al-Hadith. International Journal of Business and Social Science, 2(19), $110-116$.

Hassan, M. K., \& Girard, E. (2010). Faith-based ethical investing: The case of Dow Jones Islamic indexes. Islamic Economic Studies, 17(2), 131.

Hashim, A.M., Habib, F., Isaacs, Z., \& Gadhoum, M. A. (2017). ISRA-Bloomberg Sharī'ah stock screening and income cleansing methodologies: A conceptual paper. ISRA International Journal of Islamic Finance, 9(1), 27-42. Available at: https://doi.org/10.1108/IJIF-07-2017-004

Hkiri, B., Hammoudeh, S., Aloui, C. \& Yarovaya, L. (2017). Are Islamic indexes a safe haven for investors? An analysis of total, directional and net volatility spillovers between conventional and Islamic indexes and importance of crisis periods. Pacific-Basin Finance Journal, 43, 124-150. Available at: https://doi.org/10.1016/j.pacfin.2017.03.001.

Hussein, K. (2004). Ethical investment: Empirical evidence from FTSE Islamic index. Islamic Economic Studies, 12(1), 21-40.

Hussein, K., \& Omran, M. (2005). Ethical investment revisited: Evidence from Dow Jones Islamic indexes. The Journal of Investing, 14(3), 105-126. Available at: https://doi.org/10.3905/joi.2005.580557.

Jawadi, F., Jawadi, N., \& Louhichi, W. (2014). Does Islamic finance outperform conventional finance? Further evidence from the recent financial crisis. Working Papers No. 2014-279, Department of Research, Ipag Business School.

Khan, M. F. (1997). Social dimensions of Islamic banks in theory and practice. Paper presented at the Islamic Research and Training Institute, Islamic Development Bank Manuscript. Training Institute, Seminar Proceedings, 23.

Khan. M. M., \& Bhatti, M. I. (2008). Islamic banking and finance: On its way to globalization. Managerial Finance, 34(10), 708-725. Available at: https://doi.org/10.1108/03074350810891029.

Khatkhatay, M. H., \& Nisar, S. (2007). Shariah compliant equity investments: An assessment of current screening norms. Islamic Economic Studies, 15(1), 47-76.

Kupiec, P. (1995). Techniques for verifying the accuracy of risk measurement models. The Journal of Derivatives, 3(2), 73-84.

Medhioub, I., \& Chaffai, M. (2016). Islamic versus conventional stock market indices synchronization. African Journal of Business Management, 1O(11), 270-278. Available at: https://doi.org/10.5897/ajbm2016.8028.

Mehmood, K. (2016). Performance of islamic vs. conventional capital markets during global financial crisis: An empirical study. Doctoral Dissertation, Center of Islamic Finance, Department of Management Sciences, COMSATS Institute of Information Technology, Lahore, Pakistan.

Muhammad, M., Sairally, B. S., \& Habib, F. (2015). Islamic capital markets: Principles \&̊ practices. Kuala Lumpur, Malaysia: ISRA. 
Naveed, F., Khawaja, I., \& Maroof, L. (2020). Are Islamic mutual funds exposed to lower risk compared to their conventional counterparts? Empirical evidence from Pakistan. ISRA International Journal of Islamic Finance, 12(1), 69-87. Available at: https://doi.org/10.1108/ijif-01-2019-0012.

Ramadani, V., Dana, L.-P., Ratten, V., \& Tahiri, S. (2015). The context of Islamic entrepreneurship and business: Concept, principles and perspectives. International Journal of Business and Globalisation, 15(3), 244-261. Available at: https://doi.org/10.1504/ijbg.2015.071906.

Ratten, V., Ramadani, V., Dana, L. P., \& Gerguri-Rashiti, S. (2017). Islamic entrepreneurship and management: Culture, religion and society. In Ramdani et al. (Eds), Entrepreneurship and Management in an Islamic Context (pp. 7-17). Cham: Springer.

Rehan, F., Block, J., \& Fisch, C. (2019). Entrepreneurship in Islamic communities: How do Islamic values and Islamic practices influence entrepreneurship intentions? Journal of Enterprising Communities: People and Places in the Global Economy, 13(5), 557-583. Available at: https://doi.org/10.1108/jec-05-2019-0041.

Rejeb, A. B., \& Arfaoui, M. (2019). Do Islamic stock indexes outperform conventional stock indexes? A state space modeling approach. European Journal of Management and Business Economics, 28(3), 301-322. Available at: https://doi.org/10.1108/ejmbe-08-20180088 .

Salma, S. B. (2013). Evaluating the corporate social performance of Islamic financial institutions: An empirical study. International Journal of Islamic and Middle Eastern Finance and Management, 6(3), 238-260. Available at: https://doi.org/10.1 108/IMEFM-02-2013-0026.

Siddiqi, M. N. (2004). Riba, bank interest and the rationale of its prohibition. Jeddah: Islamic Research and Training Institute.

Siddiqi, M. N. (2014). Methodology of Islamic economics. In Handbook on Islam and Economic Life (pp. 71-89): Edward Elgar Publishing.

Tariq, M. U. (2015). Hypothetico-deductive method: A comparative analysis. Journal of Basic and Applied Research International, 7(4), $228-231$.

Tracey, P. (2012). Religion and organization: A critical review of current trends and future directions. Academy of Management Annals, 6(1), 87-134. Available at: https://doi.org/10.1080/19416520.2012.660761.

Visser, H. (2019). Islamic finance: Principles and practice: Edward Elgar Publishing.

Yusof, R. M. (2007). Stock market volatility transmission in Malaysia: Islamic versus conventional stock market. Journal of King Abdulaziz University: Islamic Economics, 20(2), 19-40. Available at: https://doi.org/10.4197/islec.20-2.2.

Zahari, A., Kamidjantono, N., \& Idham. (2009). A collection of marriage rules for the Muslim community in Indonesia: FH Untan Press.

Zulkifli, M. C., \& Saripuddin, C. O. A. S. S. (2015). Concept of business ethics in Islam: Approach to the entrepreneur. Journal of Asian Business Strategy, 5(1), 13-18. 